\title{
Making Simple Repairs: Home Security 1
}

Mary N. Harrison ${ }^{2}$

Keep your home safe and secure. When away from home, at night, or while sleeping lock your doors and windows.

Solid doors are needed for outside doors. A small peephole is a safety feature. It enables you to see who is at your door.

A chain latch on your door offers no security. Chain latches can be easily ripped off the door with pressure.

The common key-in-knob door lock does not provide a lot of protection. This door can be opened easily by using a credit card, a knife, or screwdriver between the latch and the strike plate. An intruder simply slides the credit card, knife, or screwdriver between the door and latch plate.

A deadbolt lock is also needed on the door.

\section{The deadbolt lock should be mounted on a}

solid door. If no glass is located near the door, use a single cylinder deadbolt. It has a longer plunger, which cant be opened with a credit card or knife. It opens with a key on the outside of the door. Inside the door the single cylinder deadbolt opens with a latch.

\section{If glass is near the door use a double cylinder} deadbolt. A key is used to lock and unlock the double cylinder deadbolt on the inside and the outside of the door. Special care should be taken with this lock to make sure it can be opened quickly in case of a fire. Leave the key in the lock on the inside of the door when you are home. Remove the inside key when you are away from home. Never leave a key in the lock on the outside of the door.

1. This document is FCS5234-07, one of a series of the Department of Family, Youth and Community Sciences, Florida Cooperative Extension Service, Institute of Food and Agriculture Sciences, University of Florida. Publication: May 2002. Revised: December 2005. Please visit the EDIS Web site at http://edis.ifas.ufl.edu.

2. Mary N. Harrison, professor, Department of Family, Youth and Community Sciences, Cooperative Extension Service, Institute of Food and Agricultural Sciences, University of Florida, Gainesville, 32611.

The Institute of Food and Agricultural Sciences (IFAS) is an Equal Opportunity Institution authorized to provide research, educational information and other services only to individuals and institutions that function with non-discrimination with respect to race, creed, color, religion, age, disability, sex, sexual orientation, marital status, national origin, political opinions or affiliations. U.S. Department of Agriculture, Cooperative Extension Service, University of Florida, IFAS, Florida A. \& M. University Cooperative Extension Program, and Boards of County Commissioners Cooperating. Larry Arrington, Dean 